\title{
Eug. Dubois and punctuated evolution: letters to H. Engel
}

\author{
Ellen M.A. de Looze \\ Zoological Museum Amsterdam (ZMA), University of Amsterdam, P.O. Box 94766, 1090 GT Amsterdam, \\ The Netherlands
}

Keywords: Pithecanthropus erectus, Dubois, Engel, history of biology

Marie Eugène François Thomas Duboìs (18581940 ) became famous for the discovery of a scullcap (Fig. 1), some molars and a thigh-bone, that he named 'the missing link' (Java Man Pithecanthropus erectus, Dubois 1894), found during excavations at Trinil on the island of Java in the years 1891 and 1892.

In 1887 Dubois decided to give up his promising career at the University of Amsterdam in order to do paleontological excavations in Indonesia, then 'Nederlands-Indië', in search of our forefathers (Theunissen, 1985). He entered the service of the 'Koninklijk Nederlandsch-Indisch Leger' as an officer of the Medical Board to provide maintenance for himself, his wife Anna and their new-born daughter (pers. comm. Dr Pat Shipman).

Dubois returned to the Netherlands in 1895 and he handed the entire collection of fossils over to the Dutch Government, excluding the fossils of Pithecanthropus erectus.

A few years later he was appointed Professor at the University of Amsterdam. This paper concerns correspondence between Dubois and his former student Prof. dr Hendrik Engel (1898-1981).

Engel carried out his military duties during part of the first World War until the armistice in 1918, and then he started his studies in biology in Amsterdam. In 1922 he became assistant to Prof. dr Lieven Ferdinand de Beaufort, then director of the Zoological Museum of the University of Amsterdam. He presented his thesis with Prof. dr Carl Philip Sluiter in 1925 and was curator from 1926 until 1950 and from 1950 till his retirement in 1968 professor/director of the Zoological Mu- seum (Van Benthem Jutting, 1968; Coomans et al, 1981; Coomans, 1981).

The library of the Zoological Museum Amsterdam (ZMA), Department of Mammals, houses a small file as part of the inheritance of Engel. The file comprises 23 letters and many papers written by Dubois (all signëd 'Eug. Dubois', see Fig. 5) as well as documents referring to him or his work. The 23 letters can be arranged into three groups: 2 letters are written in 1920, 6 letters date from 1931 and 15 date back to about 1936.

The first document in the file is a letter dated September 10, 1920 and addressed to: de Weledel. Heer H. Engel, Abactis N.P.F. v.h. A.S.C., Laanweg 41 , Wormerveer. In the letter, Dubois asks for information about the precise dates for the start of his lectures in physics, chemistry, pharmacy and if possible also botany and zoology. The student Engel apparently had an administrative function at the Faculty, an accessory of the Amsterdam Student Corps, and planned the lectures for the curriculum. The archives of Engel that are deposited with the Artis Library in Amsterdam contain a small part of a letter by Dubois that is identically addressed with a pre-printed stamp. In this letter Dubois thanks Engel for letting him know that his lectures will start on October 6, 1920. The notes that Engel made of the lectures are included in the file.

In 1931 Engel was elected a member of the board of editors of the new periodical Natuur en Techniek, and he wanted to write a paper on the descent of man, elaborating on the work and ideas of Dubois. He sent a draft to Dr J.J.A. Bernsen O.F.M. (1888- 


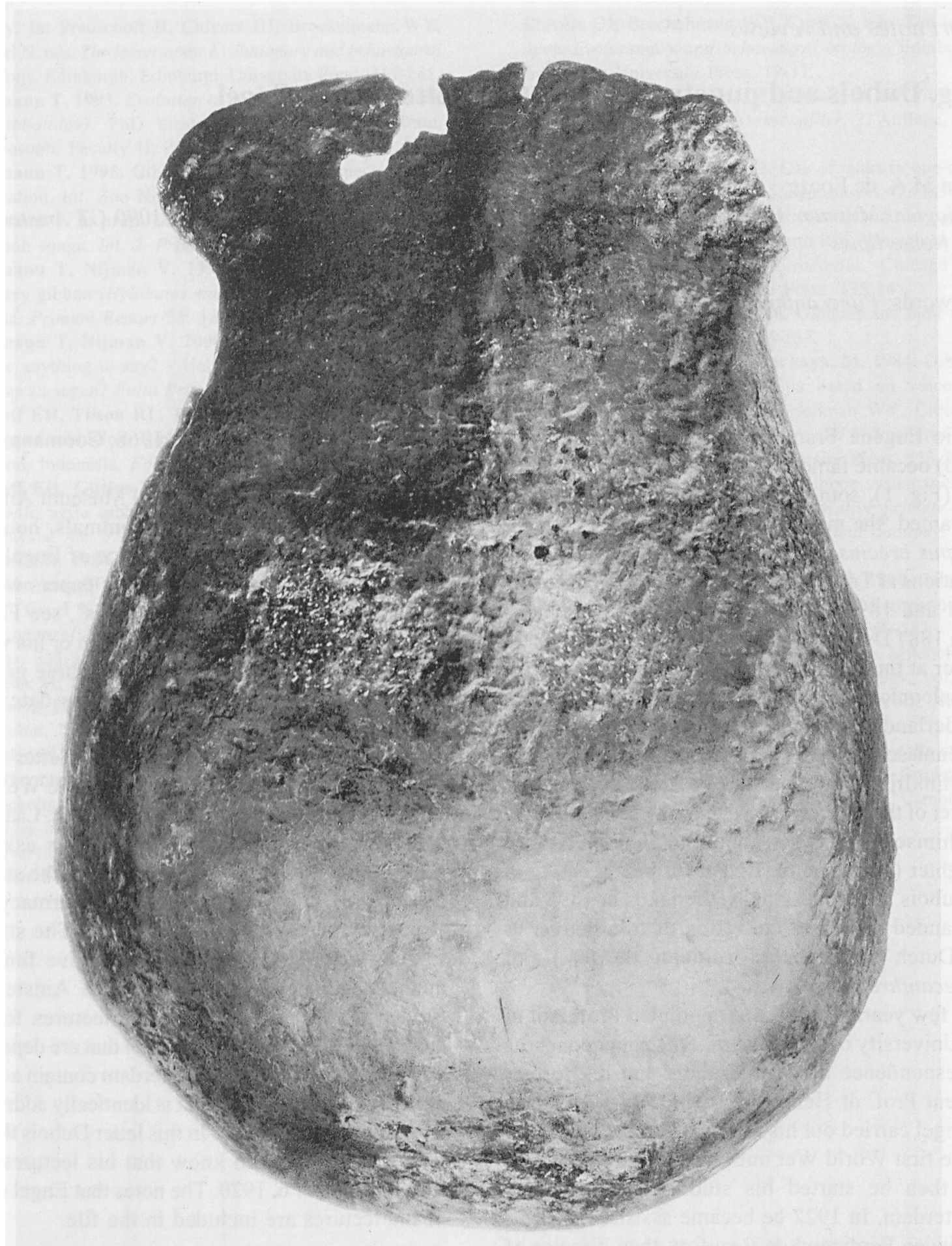

Fig. 1.

Fig. 1. The calvarium from above (real size). Transversal glabella-inion plane. Eug. Dubois published this and other photographs of his Pithecanthropus erectus in 1924 in the Proceedings of the KNAW. 


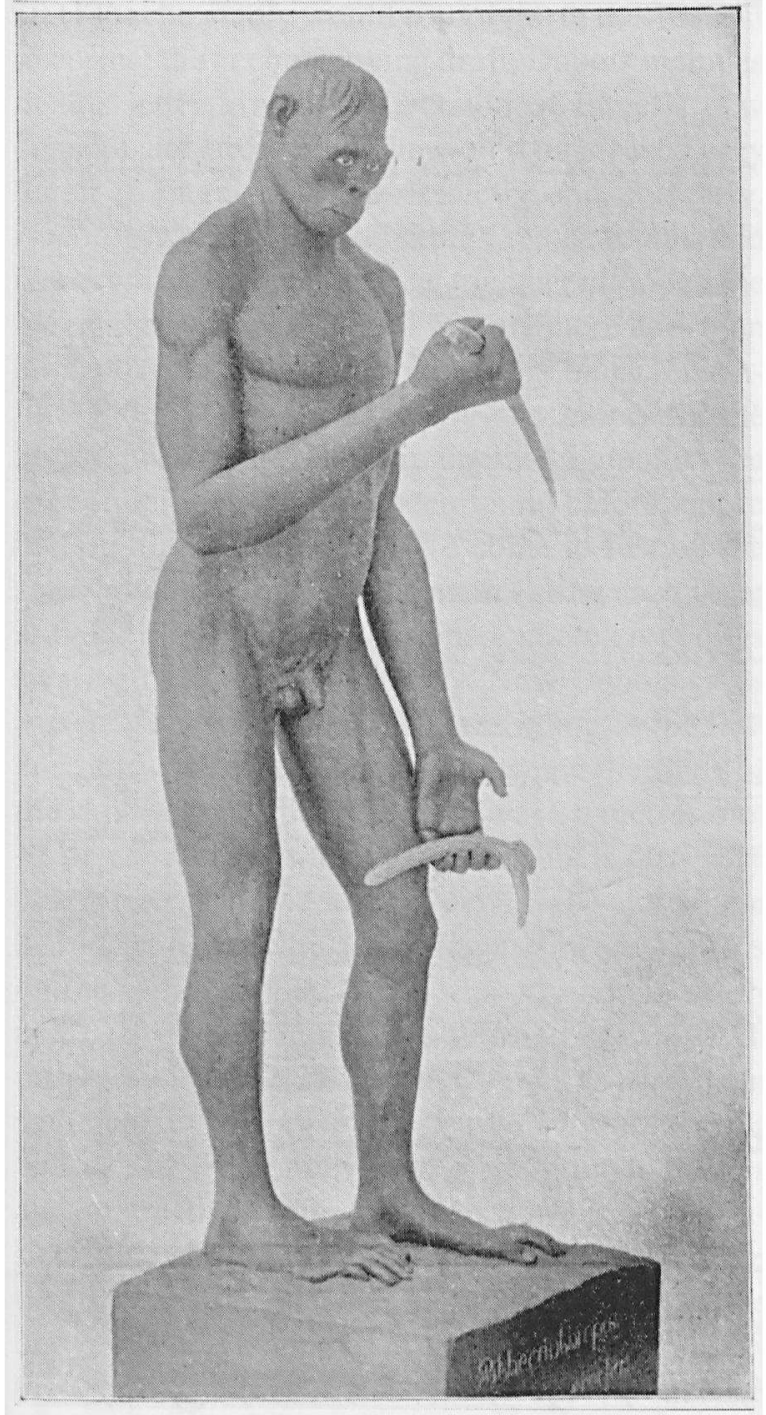

Fig. 2. The reconstruction of Pithecanthropus erectus that Dubois made for the 1900 World's Fair in Paris, France. The photograph was published by Dubois in 1902 in Petrus Camper. Nederlandsche bijdragen tot de anatomie.

1932). In 1930 the government appointed Bernsen assistant to the by then retired Dubois. Bernsen, who had presented his thesis summa cum laude to Dubois on the 23rd of June 1927, was charged to assist Dubois with the scientific preparation and description of the paleontological Trinil-collection. Bernsen writes to Engel in a letter dated January 11,1931 that, though not active in evolution, he is so "in the methodology of explanation" and he gives a broad and critical appraisal of Engel's draft. Bernsen cannot stand uncertainties and inconse- quences - he just wants the facts to speak for themselves.

At this same time Engel sent a request to Dubois for permission to illuminate his paper with a picture of Dubois as well as with a photograph of the reconstruction of the Pithecanthropus that Dubois had made on the occasion of the World's Fair in Paris in 1900 (Fig. 2).

At the time Dubois lived in Haarlem at the Zijlweg 65 and he replied on the 12th of January 1931. Dubois refers to Engel as one of his favourite pupils, and states that his ideas about evolution have changed drastically from those of a quarter of a century ago and from what still is the current opinion in scientific circles. He continues with an exposé on his new ideas: "The descent of man from the nearest primates, the apes, is, through the discovery of Pithecanthropus and the study of the phylogeny of that central structure of animal life, the brain, above any doubt". However, this descent differs from what most people imagine and cannot be understood by the current hypotheses of Darwin and Lamarck, although he respects these men highly. Dubois rejects the hypothesis of gradual evolution by natural selection, though not the mutation theory of Hugo de Vries. Instead of gradual evolution, he thinks that evolution is saltatory and to seek a 'missing link' in this light is inconceivable. He renounces his reconstruction of Pithecanthropus on these grounds since he renounces gradual phylogeny and transitional shapes. His own experiences cannot sustain Darwin's concept of natural selection. He refers Engel to several of his papers, especially Dubois (1930a, b). He ends this letter with the appeal that Engel take into consideration that his portrait represents a man who has "geirrt", but "gestrebt" [A citation from Goethes' Faust "Es irrt der Mensch, solang er strebt"] (Fig. 3).

One day later (January 13) Engel receives another short note from Dubois, stating that Dubois has lost Engel's letter, perhaps including it in the envelope of the day before, and that he has also forgotten what precisely he had written to Engel the preceeding day.

Engel took to heart both the remarks of Bernsen and the directions of Dubois and he sent a new draft directly to Dubois and asked him for comments. Dubois replied to Engel on the 29th of March 
steld. Evenwel is die aftramming nus cenigosing andork avad dan men tirh seelal nop motstelt in bepadive,

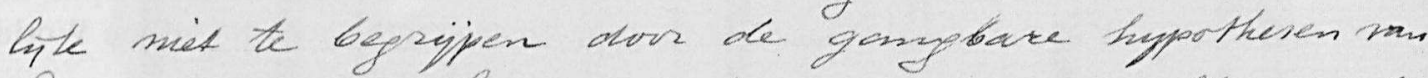
Daswin en mon damasck/mamen wa melker mesk ik werigens den diepstes coxbied koester/, hypotheren

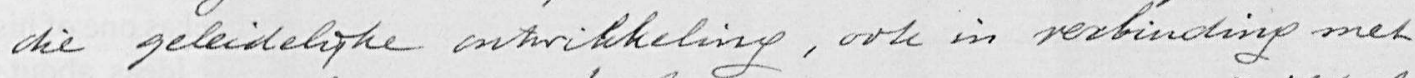
de mutatielees ran de Tries, anmemen as ontwitikelix

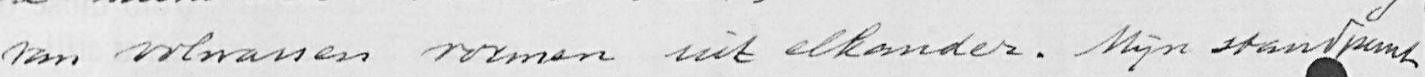

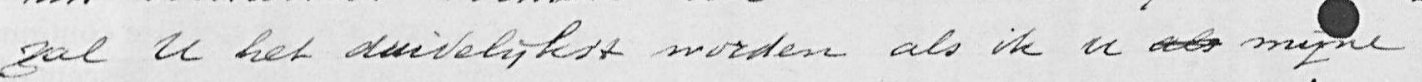
mesing te hemen gef, hax tom neamverthalenis

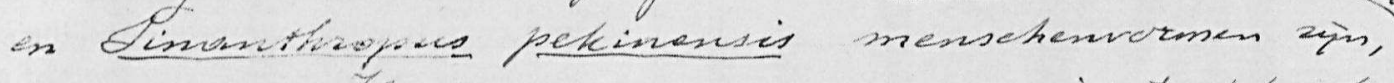

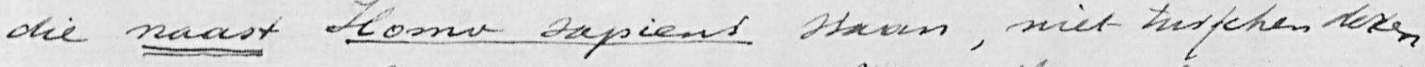

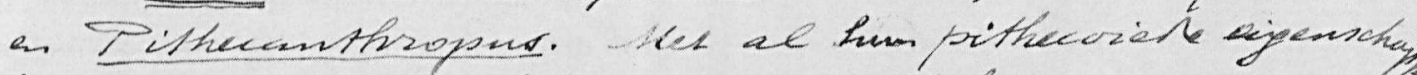

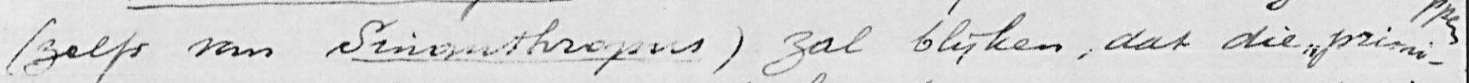
tiene" mensehazvormen dechts bifpondere adaptaties

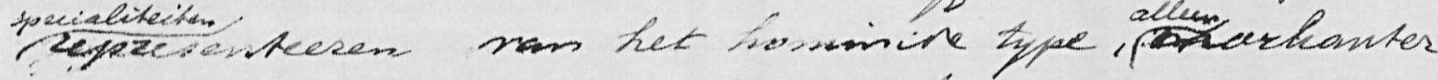
women dan die hin dim terth gedomesticedsces tomer tapeins.

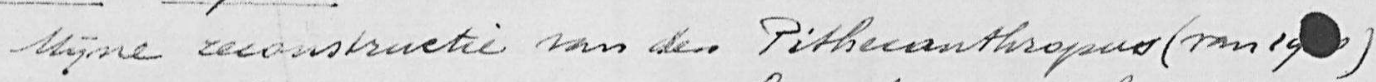

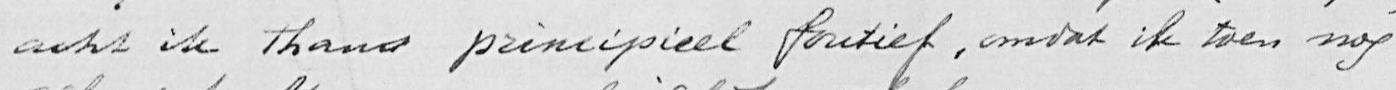

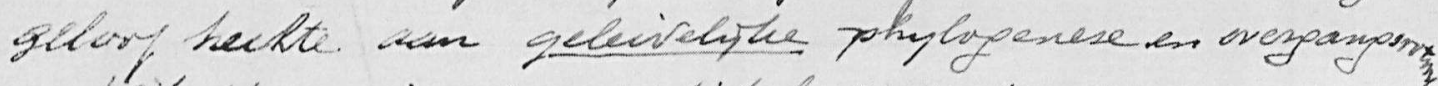

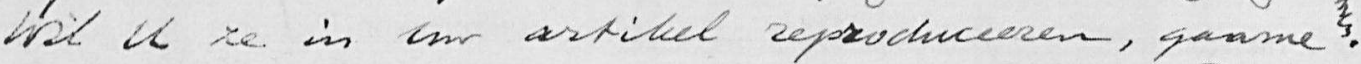

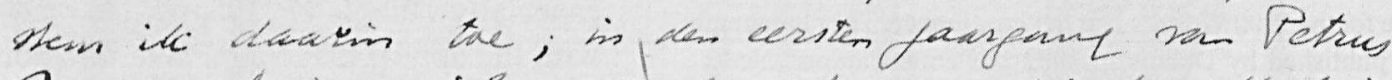

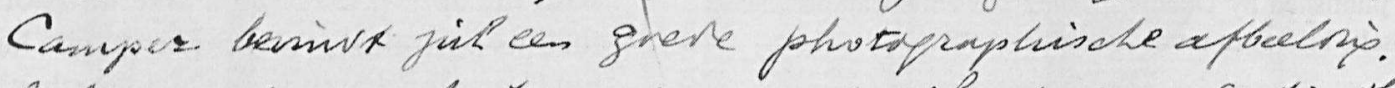

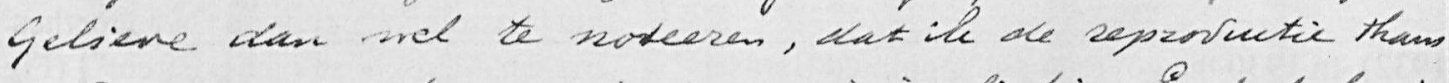
uners fon wateen, mindes misoimplintio. En torth how it Pithecouthopur mos het mising likk.

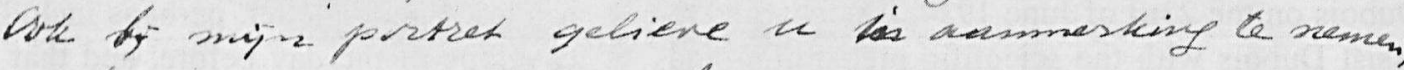

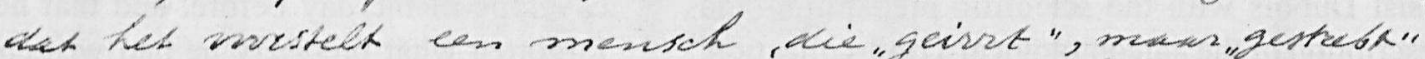

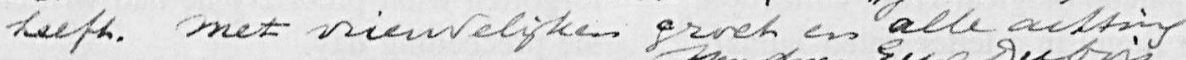

Fig. 3. Handwriting of Eug. Dubois. Page 2 of a letter to H. Engel dated January 12th 1931. In this letter Dubois explains his new views on punctuated evolution contrary to his earlier beliefs in Darwinistic gradual evolution by natural selection, and therefore he revokes his 1900 reconstruction of the Pithecanthropus. 
1931 that he gladly would comply with this request to correct the accompanying draft. Dubois includes in this letter a modified version of Engel's new concept and stresses that he would be pleased very much if Engel cites him exactly and correctly. According to Dubois, the skull-cap, the femur, and three molars certainly belong together although the two molars that were found first are more ape- than humanlike and the third molar is very much humanlike. Indeed it would be highly improbible for the bones, which are in their apelike humanity an exception of all that had been found before, not to belong together and yet have come to rest on the same day, not more than 12 metres from each other at the bottom of an old riverbed where crocodiles swarmed, or so he used to say. Now Dubois gives a correction of this distance: according to his first and oldest notes, the distance between the finds of the skull-cap and the tigh-bone was 10 metres, not 12 or 15 metres. In this letter Dubois is also very precise about Sinanthropus pekinensis and Homo neandertalensis who according to him are humans on the same level as Homo sapiens and not intermediate between humans and Pithecanthropus. In this same letter, Dubois repeats that he rejects on principal the reconstruction of Pithecanthropus because he then believed in gradual phylogenesis and intermediate forms, whereas now his cephalisation theory has changed all that. His cephalisation theory concerned the relation between brain volume and body weight among different mammalian species. Dubois believed that when a species reached a higher state that this would result in a doubling of mammalian brain cells by way of one more cell division during the embryological development of the organism. When he applied his theory to Pithecanthropus he found its brain volume to be exactly halfway between anthropoid apes and humans. Therefore he no longer was an adherent of gradual evolution, nor of natural selection. Dubois believed in an internal drive that raised the organism to a higher plain, rather than some pressure from the environment.

The next letter from Dubois is dated April 2nd, 1931. He writes that he meant his corrections to be friendly, but also because he did not want to be misunderstood. In a letter dated the 3rd of July 1931 Dubois thanks Engel for sending him the instalment of Natuur en Techniek with Engel's paper "De Afstamming van den Mensch", and he congratulates Engel, as well as the nice new periodical, and wishes them luck and all kinds of prosperity. On the 31st of August there is a letter about the photographs that were used for reproduction by Natuur en Techniek. This series of letters is supplemented by two different versions of the paper and also the proofsheets.

We now turn to a letter from Dubois dated December 29,1935 . It is a reply to a letter Engel wrote referring to the presentation Dubois gave on April 24, 1935 at the XXVth Nederlandsch Natuur-en Geneeskundig Congres in Leiden. [A copy of Engel's letter was kindly made available by Dr. J. de Vos, curator of Palaeontology and the Dubois Collection in Leiden.] Dubois writes that he feels obliged to give a small elucidation to Engel. Engel had written that he admired the flexibility of his master's scientific development, and Dubois considers this to be once more a token of Engels" sympathy that he is grateful for. From other ex-pupils, friends and colleagues, however, Dubois had received no reactions or comments on his Leiden lecture, and he is afraid that he had been misinterpreted and that people might think that he is a follower of current social views. Dubois continues that he is particular about stating that it was his own research, and the cephalisation research especially, that had brought him to his opinions, independent of the opinions of others.

A last series of letters dates from 1936. This series starts with a letter of nine pages to Engel postmarked March 11, 1936 from Leo Daniel Brongersma (1907-1994), the successor of Bernsen in Leiden. Brongersma worked as assistant at the Zoological Museum Amsterdam from 1928-1934, with some irregular work on the Dubois collection in Leiden. After the untimely death of Bernsen in May 1932 (Waage, 1932) the assistantship was temporarily filled by Miss M. Sanders [who would later become Mrs Brongersma] until Brongersma obtained the position in January 1933. In his long letter Brongersma discusses, among other things, the current disagreement between Dubois and G.H.R. Von Koenigswald (1902-1982), who had an important 
fossil find of his own. The mutual reproaches of these scientists centered on the fact that neither had been on the spot when their world famous finds had been discovered and excavated. Until now, Brongersma writes, he had had no idea about this fact. Indeed, Brongersma continues, the localities registered by Dubois are not all perfectly reliable, because Dubois used to label the fossil remains only when he was back in Holland on the basis of data from Corporals G. Kriele and A. de Winter, who in fact were in charge of the 50 convicts who carried out the excavations. On the other hand, Von Koenigswald was a geologist, not a zoologist and he had made many errors when making determinations, and his dates (and his assertions) were not all verifiable. According to Brongersma some people were of the opinion that Koeningswald's scientific reputation was questionable. However, foremost in the dispute was Von Koenigswald's claim that he had found another Pithecanthropus erectus in 1936 on Java and Dubois was devastated by this assault on his own and only Pithecanthropus. Their dispute was openly fought out in the daily newspapers (see for example Algemeen Handelsblad of 18 April and 7 May 1936). Brongersma writes that he is trying to keep himself distanced and he advises Engel to do just the same, as he has heard that Engel plans to give a lecture on the radio about Dubois.

The next sequence of letters are in reference to this speech of Engel on the VARA-radio, in a dual broadcast with Henk van Laar (1898-1955), a teacher and well known radio orator of that time. Engel spoke about "the problems of the erect Apeman."

Dubois writes a postcard to Van Laar dated June 3rd, 1936, in which he states that he must limit himself in the scientific businesses in which he is involved with Van Laar and Engel. It is getting too much for him. He has other urgent work to do because of the harm that has been brought on from the Indies [the activities of Von Koenigswald]. Dubois reminds Van Laar to point to the importance of the 5 new femora that Bernsen recovered (Fig. 4) in the fossil material of the collection, finds that, according to Dubois, completely change the whole Pithecanthropus issue.

An express delivery dated June 13th, 1936 to

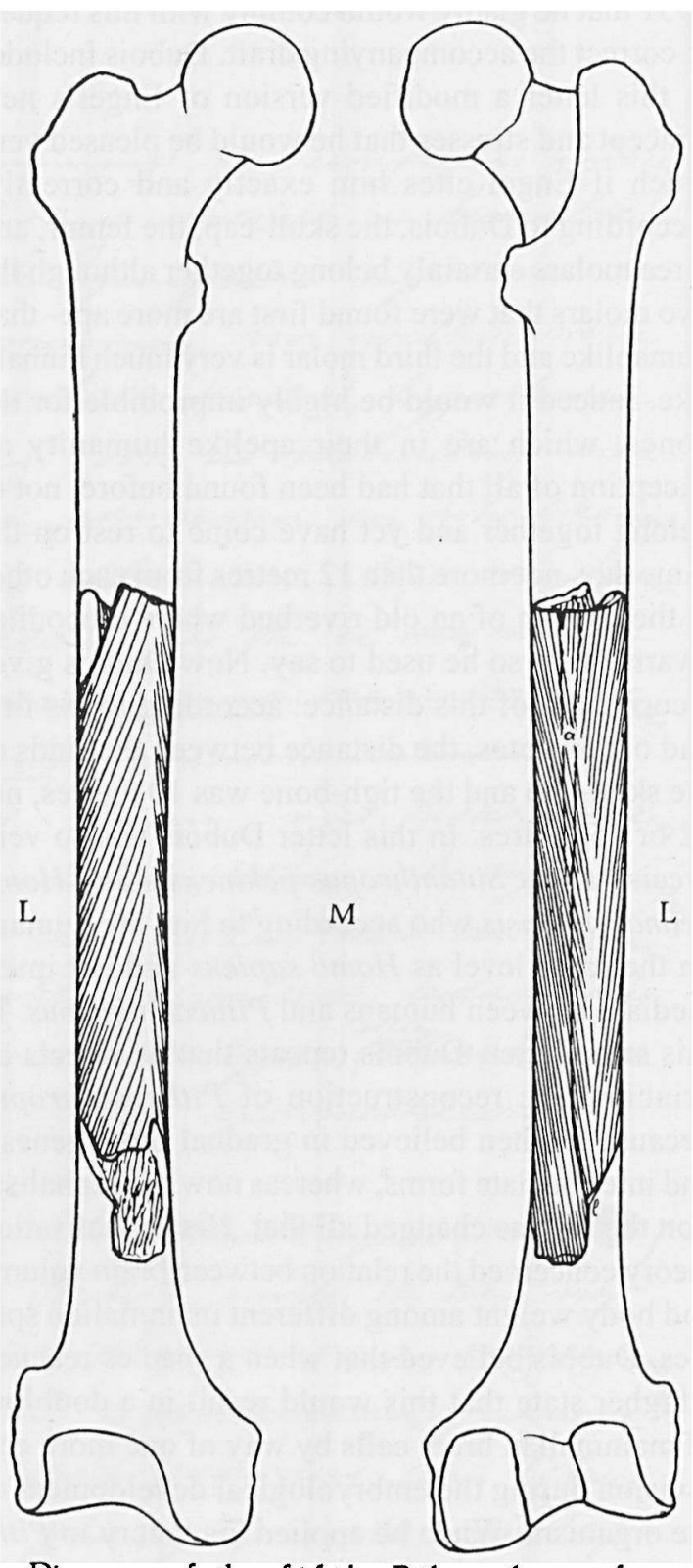

Diagrams of the $f$ if th Pthccanthropus femur, from before (left diagram) and from behind (right diagram). The fragmental shaft located in the outlined entire right femur $1 / 3 . M$ medial side, $L$ lateral side, a linea aspera, $i$ its divergent Labium laterale.

Fig. 4. The 5th much disputed femur (pers. comm. P. Shipman) as presented by Eug. Dubois in the Proceedings of the KNAW in 1935. 
Engel contains a complete draft of the radio speech written by hand by Dubois, including the discussion of the cephalisation theory and many examples. Dubois proposes that Engel follow this draft completely, with only oratory and didactic amplifications from Engel's hand, rather than making use of Engel's own draft. Dubois thinks this is the best way to achieve their goals.

On the 15th of June of the same year Engel writes to Dubois that he is very thankful and that he shall make use of the draft. He continues with mentioning compensation for the expenses he, Engel, has incurred: travelling expenses, telephone expenses, cycle store, tram, bus, 4 express postcards, various porti, for a total of $f 2,90$. On the 16th of June Dubois transferred a remittance of $\mathrm{f} 3,33$ for Engel and f 6,09 for Van Laar. On June 18, 1936 Dubois writes to Engel again that he made an error in his script: the distance between (bird's-eye view of) Trinil and Ngawi is not $7 \mathrm{~km}$, but must be $10 \mathrm{~km}$. On the 24th of June 1936 the hour has arrived for Engel to give his speech in a broadcast of the VARA from 19.40-20.00 hours. We have two typewritten versions of the speech, one a draft from Engel, and the other the final speech, in addition to the handwritten concept of Dubois.

From a letter from Dubois dated July 5th 1936 to Dr A. Schreuder, it is obvious that she, with the approval of the gentlemen Dr Jacob Heimans and Dr Thijsse, had asked permission of Engel and Van Laar to publish their radio speeches from the 24th of June in the periodical De Levende Natuur. [Antje Schreuder (1887-1952) was also an ex-pupil of Dubois. From 1917 until he retired in 1929 she was his assistant after which she became an honorary staffmember of the Zoological Museum Amsterdam, where she achieved an international reputation for her knowledge of early pleistocene vertebrates (Van der Feen \& Van Benthem Jutting, 1952).] She had asked Engel to provide a portrait of Dubois and the photographs "of the skull-cap and thigh-bone as they had been published by the Royal Netherlands Academy of Sciences, or KNAW. In his letter, Dubois raises objections: a portrait is fine, but he likes best that made in 1925, when he was still in full, or rather unlimited, action (Fig. 5).

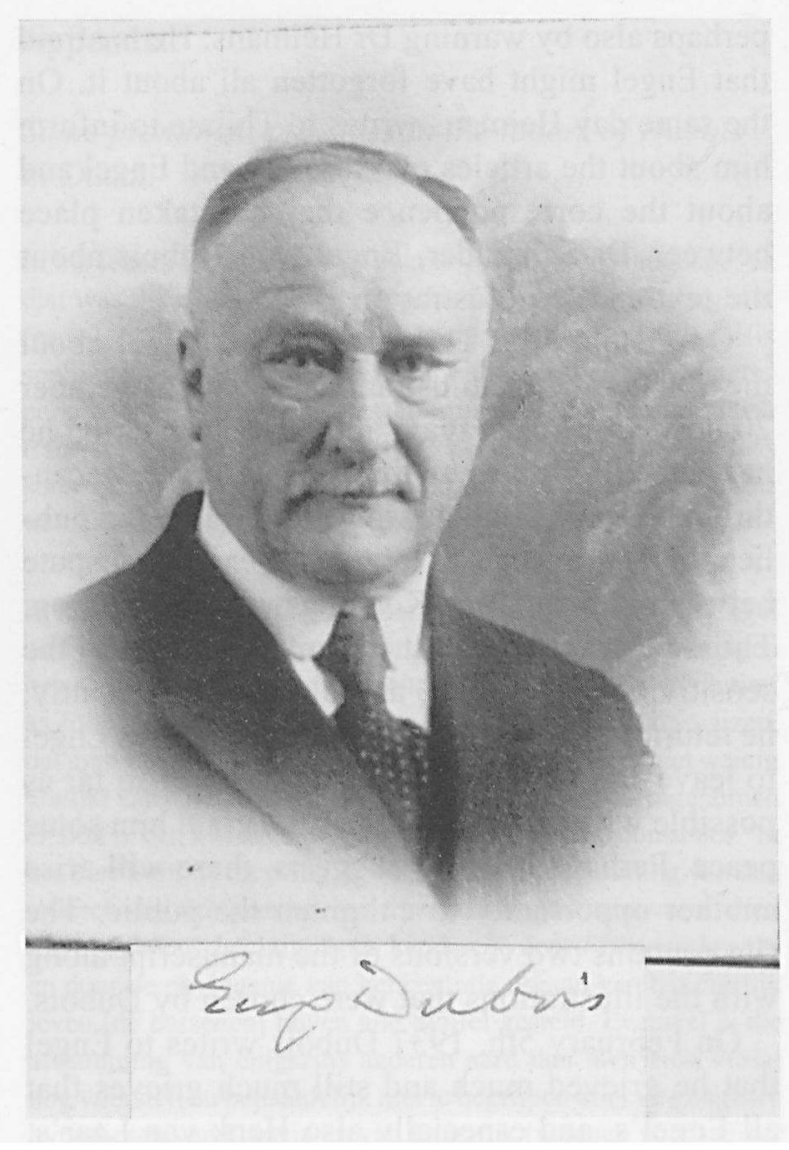

Fig. 5. Portrait of Prof. dr Eug. Dubois with his signature. The photograph was made in 1925 when Dubois was "still in full action". The photographer was Mr F. Stachhouwer of Dubois' laboratory in Amsterdam.

He proposes other photographs of the brains of Pithecanthropus and Sinanthropus and other pictures of the femur. He announces as much also to Engel in a postcard postmarked July 6th, on the 8 th he.writes a letter about the illustrations and proposes alterations in the article. On the 9th of July there is another letter with more changes and additions. On the 10th of July there is again a postcard to Engel with corrections and amplifications to the text, and again on the 13th of July he informs Engel of one more addition. On July 16, 1936 Dubois writes Engel that he does not wish for the reconstruction of Pithecanthropus erectus to be inserted in the article for De Levende Natuur.

On July 17, Dubois sent a postcard to Dr Thijsse about the reconstruction of Pithecanthropus from the year 1900 that has now been proven wrong. He begs Thijsse to exclude it from the article, 
perhaps also by warning Dr Heimans. $\mathrm{He}$ is afraid that Engel might have forgotten all about it. On the same day Heimans writes to Thijssse to inform him about the articles of Van Laar and Engel and about the correspondence that has taken place between Dr Schreuder, Engel, and Dubois about the text and the illustrations.

On October 16, Thijsse writes to Engel about the articles and the illustrations, and on November 20 he writes Engel again about a conversation he has had with Dubois on the topic of the "Pithecanthropus-affair". Dubois wants to hold up the publication of the article as long as the existing dispute between him and Von Koeningswald is going on. Thijsse thinks they must resign themselves to the sensitivities of Dubois, and although reluctantly, he returns all the papers to Engel. He advises Engel to leave "the old grey scientist" alone in so far as possible with all his vexations and grant him some peace. Perhaps later, he suggests, there will arise another opportunity to enlighten the public. The file contains two versions of the manuscript along with the illustrations that were chosen by Dubois.

On February 5th, 1937 Dubois writes to Engel that he grieved much and still much grieves that all Engel's, and especially also Henk van Laar's, work for De Levende Natuur is, for the time being, in vain. It seems to him best that they resign themselves to the situation. The right cause of truth will at last, however, be victorious. Dubois welcomes the communication that Dr Von Koenigswald had been satisfied with the friendly treatment during his visit with Dubois and Brongersma. He writes further that he will not be attending the symposium in March that will take place in Philadelphia on the prehistory of humankind, although he was kindly asked to participate.

Meanwhile Engel received a postcard from Dubois, dated September 29, 1936, congratulating him with the birth of his son, Ernst Peter. Because the child is now 4 weeks old, he is the same age as the Homo modjokertensis-child. Dubois thinks that now is the moment that the differences with the most-primitive of all human children can be measured and by comparison becóme known. He proposes that Engel and his wife note down weight and length, besides measuring the circumference of the cranium, the cranial length, breadth and height.
This letter is the conclusion of the 23 letter file. It is clear that the older Dubois had became vulnerable and insecure by all the criticisms of his theories, the more so as they often were of a personal nature (see e.g. Von Koenigswald, 1951). Dubois was a great scientist, ahead of his time with many of his conceptions; although he could be difficult to deal with, he also could be very cordial and friendly; this can be appreciated in his correspondence with Engel.

The file, that will be handed over to the Artis Library of the University of Amsterdam where the Engel archives are deposited, comprises, besides the letters mentioned above, various articles and press cuttings - some of these will be mentioned in the bibliography. For the remainder the reader is referred to the comprehensive bibliography in Theunissen, 1985.

\section{Acknowledgements}

I am grateful to Dr P.J.H. van Bree, former curator of the Department of Mammals of the Zoologícal Museum Amsterdam, who one day in 1997 dropped the file on my desk, and encouraged me when I proposed to write a paper about the letters. Dr Arne Mooers kindly supervised the English version of the manuscript. Mr Louis A. van der Laan made the photographic illustrations figured in this paper. Mrs T.G. Prins was my guide during my adventures with the computer. Finally I want to thank Dr A.G. Veerbeek, her colleagues and the staff of the Department of Cardiology of the Slotervaart Ziekenhuis in Amsterdam. They gave me back my life on the night of the 4th of December 1997 and they took care on several more occasions during the months to follow that I did not lose it again. I would like to share my well-being with all of them in this unusual way.

\section{References}

Benthem Jutting WSS van. 1968. Dr. Hendrik Engel, Zoologist and Historian, Curator and Professor. Beaufortia 15(179): 1-5.

Brongersma LD. 1941. De Verzameling van Indische Fossielen (Collectie-Dubois). De Indische Gids 63: 97-116.

Coomans HE. 1981. Prof. Dr. Hendrik Engel (1898-1981) als malacoloog. Basteria 45: 91-96.

Coomans HE, Jeekel CAW, Stock JH. 1981. In memoriam Prof. Dr. H. Engel (1898-1981), Vakbl. Biol. 14: 313.

Dubois Eug. 1894. Pithecanthropus erectus eine menschenaehnliche Uebergangsform aus Java. Batavia: Landesdruckerei. 
Dubois Eug. 1902. Données justifications sur l'essaì de reconstruction plastique du Pithecanthropus erectus. In: Camper $\mathrm{P}$, Nederlandsche bijdragen tot de anatomie 1: 237-241.

Dubois Eug. 1924. Figures of the calvarium cast, a fragment of the mandible and the teeth of Pithecanthropus erectus. Proceedings of the Section of sciences. Koninklijke Nederlande Akademie van Wetenschappen, Vol XXVII (nos. 5 and 6): 460, Plate 1.

Dubois Eug. 1930a. Phyloblastese, het beginsel der phylogenese en de grondvoorwaarde der aanpassingsbetrekkìngen. Verslag van de gewone vergadering der Afdeeling Natuurkunde, Deel XXXIX(7): 124-127.

Dubois Eug. 1930b. Die phylogenetische Groszhirnzunahme autonome Vervollkommnung der animalen Funktionen. Biologia generalis 6: 247-292.

Dubois Eug. 1935. Pithecanthropus erectus als organisme. In: Handelingen van het 25ste Nederlandsch Natuur- en Geneeskundig Congres, Leiden, 23-25 april 1935: 147159.

Dubois Eug. 1935. On the gibbon-like appearance of Pithecanthropus erectus. Proceedings of the Koninklijke Nederlandsche Akademie van Wetenschappen, Vol. XXXVIII (6): 578-585.

Dubois Eug. 1936. Nĩeuwe Pithecanthropus ontdekt? Algemeen Handelsblad, 18 april 1936. Avondblad 4e bl. 11.

Dubois Eug. 1936. Over fossiele menschen en Pithecanthropus. Nieuwe Rotterdamsche Courant, 26 Juli, 2 en 12 Augustus 1936. Gedrukt ter N. R. C., Rotterdam, Augustus 1936: 1-20.

Engel H. 1931. De Afstamming van den Mensch. Natuur en Techniek 1(3): 98-101.

Feen PJ van der, Benthem Jutting WSS van. 1952. Dr Antje Schreuder, Amsterdam, 15 november 1887-Amsterdam, 2 februari 1952. Geologie en Mijnbouw, Nw. serie nr 4, 14: 121-125.

Koenigswald GHR von. 1936. Pithecanthropus erectus Antwoord dr. Von Koenigswald op den brief van prof. Dubois in Alg. Hbl, van 18 April 1936. Algemeen Handelsblad, 7 mei 1936. Ochtendblad 3e bl. 5 .

Koenigswald GHR von. 1951. 60 jaar Pithecanthropus. Verslag van voordracht gehouden voor de Koninklijke Nederlandse Akademie van Wetenschappen - Amsterdam, DL.LX(8): 86-91.

Pinkhof M. 1938. Prof. dr. Eug. Dubois tachtig jaar. Algemeen Handelsblad, 26 januari. Avondblad 3e bl. 9.

Shipman P. 2001. The Man who Found the Missing LinkEugène Dubois and his Lifelong Qliest to Prove Darwin Right. Simon \& Schuster, New York.

Theunissen LThG. 1985. Eugène Dubois en de Aapmens van Java - Een bijdrage tot de geschiedenis van de paleoantropologie - Proefschrift. Uitg. Amsterdam: Rodopi.

Waage GH. 1932. In memoriam pater dr. $J_{x} J_{x} A \times$ Bernsen O. F. M. Natuurhistorisch Maandblad 21(6): 73-74.

Accepted: 22 December 2000

\section{Appendix}

\section{Some prominent passages in the letters of Dubois in Dutch.}

In his letters Dubois used of course 19th century language, as that was the century he received his education in. His style is formal, polite, erudite and with a great richness of titles. His spelling and choice of words differ considerable from contemporary dutch language which is unfortunately all lost in an english translation of the paper. To try to accommodate for this loss some of the most prominent passages in these letters of Dubois in the dutch language, follow here:

In the letter of the 12th of January 1931 Dubois refers to Engel as: " $U$, een mijner leerlingen aan wien ik de beste herinneringen bewaar, ...* $\times$ He explains his change of ideas about evolution as follows: "Maar ik moge er toch, in ieder geval, op wijzen, dat mijn standpunt tegenover het genoemde probleem niet weinig afwijkt van dat hetwelk nog in breede kringen wordt ingenomen en ook ik een kwart eeuw geleden innam" and he continues "In het kort is mijne meening de volgende. De afstamming van den mensch van den hem hêt naast bestaanden primatenvorm, dien wij in de menschachtige apen kennen, is door Pithecanthropus en door de phylogenie van het centrale orgaan van het dierlijk leven [de hersenen] boven alle twijfel gesteld. Evenwel is die afstamming van enigszins anderen aard dan men zich veelal nog voorstelt en bepaaldelijk niet te begrijjpen door de gangbare hypothesen van Darwin en van Lamarck (mannen voor welker werk ik overigens den diepsten eerbied koester), hypothesen die geleidelijke ontwikkeling, ook in verbinding met de mutatieleer van de Vries, aannemen en ontwikkeling van volwassen vormen uit elkander." ..."mijne reconstructie van den Pithecanthropus acht ik thans principiêel foutief. Omdat ik toen nog geloof hechtte aan geleidelijke phylogenese en overgangsvormen". He ends this letter: "Ook bij mijyn portret gelíeve $U$ in aanmerking te nemen, dat het voorstelt een mensch, die "geirrt", maar "gestrebt"hat. [Citation from Goethe's Faust ]

From the letter of 29th of March 1931: "Aan Uw verzoek, bij Uw schrijven van gisteren, om bijgaand artikel te corrigeren voldoe ik gaarne." The two first found molars are "meer aapdan menschachtig, de laatstelijk gevondene is zeer menschelijk - In mijn oudste aantekening vind ik $10 \mathrm{~m}^{*}$ *

From the letter dated 2nd of April 1931: "Mijne correcties zijn inderdaad vriendelijk bedoeld maar komen toch ook wel voort uit mijn wensch om zelf niet onjuist begrepen te worden."

On the 3rd of July: "... dat Uw artikel "De Afstamming van den Mensch" bevat", he wishes Engel "en het mooie nieuwe tijdschrift van harte succes en ook overigens alle voorspoed."

Then the letter from the 29th of December 1935: "....gevoel ik mij tot een kleine toelichting gedrongen, omdat ik Uwe persoonlijke waardering van Uwen oud-leermeester steeds op hoogen prijs gesteld heb". " ... dat het hier betrof een volte face om de zich wijzigende maatschappelijke inzichten." "... eraan hecht te verklaren, dat eigen onderzoek (het U bekende cephalisatieonderzoek vooral) mij daartoe gebracht heeft, onafhankelijk van 
de meningen van anderen.". What Engel praised as flexibility "betreft dan ook slechts gevonden feiten". And he ends as follows: "Zie daar wat ik een van mijn meest sympathieke oud-leerlingen mij gedrongen gevoel te schrijuven". " $\ldots$.. de beste nieuwjaarswenschen voor U Vrouw en Kind".

The 3rd of June 1936 on the postcard to Van Laar that he has urgent matters to do: "naar aanleiding van het uit Indiẽ berokkende kwaad,"

And on the 5th of July to Mejuffrouw Dr A. Schreuder: "Mijn portret, goed, maar dan lijkt mij het best dat portretje (van 1925), toen ik nog in volle, althans onbelemmerde actie was,"

In the letter of the 5th of February 1937 he writes: " $\ldots$ dat al Uwe moeite en vooral ook die van Henk van Laar voor "De
Levende Natuur" voorlopig te vergeefs is geweest. Maar het lijkt mij het beste dat wij ons daarin schikken. De goede zaak der waarheid zal tenslotte het toch winnen. Uwe mededeling over het bezoek van Dr. Von Koenigswald en zijne voldoening over de vriendelijke behandeling van mij en Dr. L. D. Brongersma ondervonden doet mij veel genoegen."

Finally the letter dated 29th of September 1936: "Uw zoon Ernst Peter, thans bijna 4 weken oud, gelijk het "Homo modjoken-

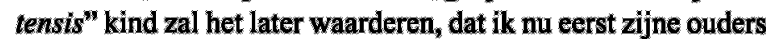
gelukwensch met zijne geboorte daar nu het verschil met dat primitiefste van alle bekende menschenkinderen door vergelijking blijken kan." 